AperTO - Archivio Istituzionale Open Access dell'Università di Torino

\title{
Joseph de Maistre and Italy
}

\section{This is the author's manuscript}

Original Citation:

Availability:

This version is available http://hdl.handle.net/2318/90248

since

Publisher:

BRILL

Terms of use:

Open Access

Anyone can freely access the full text of works made available as "Open Access". Works made available under a Creative Commons license can be used according to the terms and conditions of said license. Use of all other works requires consent of the right holder (author or publisher) if not exempted from copyright protection by the applicable law. 


\section{JOSEPH DE MAISTRE AND ITALY}

\section{Marco Ravera}

It is very likely that Joseph de Maistre would not have been very much interested in the subject of the reception of his own thought in Italy. ${ }^{1}$ He did not consider himself Italian-and, in spite of his being Francophone, he did not consider himself French either-but only and exclusively Savoyard (or rather, in the last phase of his life, Savoyard and European at the same time, but certainly not Italian). His eyes and his attention were always drawn to France; and the early impulses for the national unity of Italy that happened a few years after the Restoration-a legacy of that Napoleonic epos which he abhorred so much-left him perplexed and astonished, rather than disturbed and troubled. It is true that, given that he died at the end of February 1821, he could not witness (or, we might say, he was spared the sight of) the early risings for unity. However, his opinion in this respect is condensed, through reflections enriched by that sarcastic irony which distinguishes several of his writings, in some famous claims included in the letter to the marquis d'Azeglio ${ }^{2}$ of 21 February 1821-that is, three days before his death-where, with ill-concealed scepticism, he wonders whether and to what extent one can call himself 'Italian'. After having thanked his correspondent for having sent to him a basketful of fruit, the nearly expiring lion still shows his claws and, taking his cue from some considerations on Piedmont and Italy made by d'Azeglio in the letter that accompanied the gift, added long reflections on this subject. The main point is clarified in the following quotation:

\footnotetext{
1 A decisive help in preparing the definitive English version of this essay, based on the unpublished work originally written by me in Italian, came from my young colleague Paolo Diego Bubbio. He is more Anglophone than I, as is evident from his academic positions as Research Fellow at the University of Sydney and as Teaching Fellow at the University of Aberdeen, and from the large number of philosophical papers that he has written in English. Therefore, I am most grateful to him for his help.

2 To avoid confusion, it has to be stressed that Maistre's correspondent was the marquis Cesare Taparelli d'Azeglio (1763-1830), father of the better known Massimo d'Azeglio, who was his fifth son. The latter is particularly remembered for the famous Lettera sul romanticismo (Letter on Romanticism), written to him by Alessandro Manzoni in 1823.
} 
The greatest misfortune to a nation is certainly to have to obey to another,... The wise man who meditates upon this huge problem does not really know what to think when someone mentions the Italian spirit (or that Italian unity one sometimes hears about),... seeing what a fearsome catastrophe it would be necessary to go through in order to revive Italy. This country is paying dearly for the terrible unity that once tore the world to shreds.

Here Maistre is clearly referring to the force-fed unity of the Napoleonic Empire. And with regard to the role of Piedmont, he goes on with irritating comments, which were in countertendency with respect to the spirit of the age, and nevertheless somehow prophetic:

Piedmont is in itself a whole that cannot blend with anything. ... It cannot even increase its extension, as the land that would be added to it would be a foreign land that Piedmont should rule, and it would never be a part of Piedmont itself. Therefore, it can exist only in two ways: either as it is and as it has always been, in its old and current dimensions ..., or dragged into a general revolution, which would make it the province of a great State. ... And it would be quite a political problem to examine whether Piedmont could be happier and more flourishing as a great province or as a small State. As far as I am concerned, I would opt for the second option... I don't delude myself, and I know (as I know that three angles of a triangle equal two right angles)... that the throne cannot be higher without being more distant. ${ }^{3}$

Therefore, the idea of Italy as a unified (or, better, unifiable) nation was something completely extraneous to the political view of Maistre, who, as is known, in the last period of his meditation was rather looking at the possibility of a Europe somehow united and pacified in a sort of confederation of states that should have had the Pope as an arbiter to solve their disputes: a utopian dream of "perpetual peace" in clear countertendency with respect to the system of the Congress of Vienna, a police system that, although nourished with quasi-mystical elements in the view of Czar Alexander and of some of its inspirers, among whom Franz von Baader played a prominent role, was interpreted more concretely and pragmatically in Vienna and Berlin. Maistre was and always remained quite sceptical about the efficacy, solidity, and durability of the restoration plan conceived at the Congress of Vienna; in this respect he was always of a divided and contradictory inner disposition. It was the contradiction of a man who, eventually returned from Russia to Turin and attending a Council with King Vittorio

\footnotetext{
3 Joseph de Maistre, Oeuvres complètes, 14: 256-9.
} 
Emanuele I in which several ministers seemed to have given in to the impulse to elaborate more and more projects, burst out saying the famous and lapidary sentence: "Gentlemen! The earth is quaking, and you want to build?" Exactly: "the earth was quaking," and the early impulses for Italy's national unity, somehow perceived by Maistre, did not represent for him anything but an aspect of this earthquake. The revolution, of which Napoleon was an effect and for which the Congress of Vienna was a totally insufficient and inadequate (if not naïve) response, allait son train. Men could certainly not stop it before it exhausted its force, propulsive and dissolving at the same time; and certainly it could not be stopped by the projects of the ministers of the Kingdom of Sardinia.

"Prophet of the past" 4 - as he was sharply defined with a completely paradoxical expression that he would not have rejected ${ }^{5}$-insofar as he was linked to the ancien régime, like all the great conservatives (as opposed, or better antithetical, to the mediocre conservatives, who merely looked at the past), Maistre looked to the past and to the remotest future at the same time. But he was essentially unable to see the immediate future, that "immediate" future which resulted, in about half a century, in the unification of Italy, a country that most likely for him was nothing more than "a geographical expression" (as claimed by Prince Clemens von Metternich), which therefore excluded the Alps and, at best, started from the Po valley. This was, by the way, in accordance with a consolidated and universal view, at least before the Risorgimento. Goethe, for example, in Italian Journey, does not consider himself to be in "the land where lemons bloom" until he arrives in Verona (14 September 1786), as he ponders while looking back towards the Adige valley that he just descended, which, although languages "start to blend" in its southern part, is still Tirol, up to the last rocky cliffs that lead to the green plain. After all, in the utopian view of European unity mentioned above-not realized thanks to the force of Napoleon's bayonets and guns-but grounded on religion, what importance should the persisting division of the Italian peninsula in several States, some larger and some smaller, have ever had for Maistre, once this division had been overcome and embraced by a really "European" peace?

\footnotetext{
${ }^{4}$ On Maistre's reputation as a "prophet of the past," see, in this volume, Kevin Erwin's essay, "Le mystique de la tradition: Barbey Worships at the Altar of Joseph de Maistre."

${ }_{5}$ Claude-Joseph Gignoux, Joseph de Maistre, prophète du passé, historien de l'avenir (Paris: Nouvelles éditions latines, 1963).
} 
In the medium term, however-and we ourselves do not know yet what will happen in the "long" term (although it is true that we now live in a Europe that is somehow "unified," not by religion and even less by weapons, but in a completely secular way by money, and the role of arbiter is not assigned to the Pope, but to the managers of the European Central Bank)-everything went against his predictions, his hopes, and his expectations. Thus Italy was united as a State, eventually attacking with weapons the same Papacy that Maistre would have wished as an arbiter and a superior and impartial judge of European destinies, and making a rift between State and Church (in a country whose great majority was Catholic) that only after another half a century would have found a relative (and essentially all but solid) composition in the Lateran Pacts. And the role played by the Liberi Muratori (and by the other secret societies connected with them) in the events that led to national unity (as the most recent and shrewdest historiography, such as Denis Mack Smith's work, has shown with several documents and arguments) represents a crowning irony, if we think of the complex love-and-hate relationship that Maistre had with Freemasonry, a relationship that clearly emerges from the dialogue between the Senator and the Count in Les soirées de Saint-Pétersbourg. In short, once again, Wilhelmsbad's "secular" party had won, and the wing to which Maistre belonged was on the losing side. ${ }^{6}$

\footnotetext{
6 The theme of the Masonic militancy of the young Maistre, his illusions in this respect, his membership in the mystical-esoteric Lodges that were not in conflict with the Roman Church, his encounter and fight with Martinism, and his 'indirect' participation to the Congress of Wilhelmsbad (which was the place of a heated debate between the 'rationalist' and the 'mystical-illuminist' tendencies of Freemasonry, and in which the latter was defeated) is documented by the Mémoire addressed to the Duke of Brunswick by Maistre himself for the occasion. Volumes have been written on this subject, particularly in France, by Vermale, Dermenghem, Vuillaud, and, above all, the research published in the Revue des études maistriennes thanks to the untiring activity of Jean-Louis L. Darcel, and particularly in the precious 1979-1980 issue, including the Proceedings of the Chambéry Congress held in 1979 on Lumières et maçonnerie dans la seconde moitié du XVIIIe siècle. Here I can mention this subject only briefly; however, it has to be stressed that some important contributions in this respect have also been published in Italy. Although strictly speaking the excellent works of Jean Rebotton, a scholar from Val d'Aosta, cannot be included in "Italian" historiography, either because they have been published in Italy but written in French (such as the Études maistriennes (Aosta: Bibliothèque de l'Archivium Augustanum, 1975)), or because they have been published abroad (such as the Écrits maçonniques, Geneva: Slatkine, 1983), it is worthwhile to mention at least some parts of the Proceedings of the Congress Joseph de Maistre between Enlightenment and Restoration, which was held in Turin in
} 
Thus, unified Italy, its culture, and its historiography did not forget to return the discourtesy to him who had so clearly shown that he was not taking seriously their very possibility; and for some decades a deafening silence, not significantly interrupted by irrelevant works (such as Giuseppe Saredo's monograph, published in Turin in 1860), wrapped the work of a thinker whom Rosmini-who today has been beatified (maybe because he has been "normalised"?), but, at that time, was another "problematic" character, as is well known, both for the Church and the State-defined as "saint De Maistre." The Holy See had already looked suspiciously and warily at $\mathrm{Du}$ pape, despite an almost immediate Italian translation, together with the translation of De l'église gallicane, both edited by Giuseppe Marchetti and Giovanni Benacci and published in Imola in 1822 and 1823-but they are almost useless and unreliable works, as it often happens with nineteenth-century translations. In short, the lack of interest of Italy for him who, for his part, had not shown any interest in Italy itself, was total for a long time.

In fact, it is necessary to go so far as to the twentieth century (and the late twentieth century) in order to find Maistre's name in works by Italian philosophers and historians, or by Italian interpreters of his thought. This happens according to a twofold trend. On the one hand there is the historiographical and documental interest, which reemerges and is expressed in new editions or better translations of some of his main works, and above all in the attempt to set such a difficult, outdated and 'distant' figure in his historical background, through monographs and specialist studies that are often valuable. On the other hand-and this is what is most interesting for the purpose of this essay-there is the progressing discovery of his underground influence on important trends of twentieth-century Italian philosophy, even of the second half of it, which, prima facie, could seem completely

\footnotetext{
1974 and published the following year by the Centro Studi Piemontesi. The proceedings are multilingual because of the participation, besides the Italians Gianni Perona, Mario d'Addio, Enrico De Mas, Maria Teresa Bovetti Pichetto, Mirella Lolli Larizza, Alexandre Passerin d'Entrèves, and Luigi Marino (who was the organiser of the event and editor of the volume), of important foreign scholars such as Robert Triomphe, Richard A. Lebrun, and Jean René Derré. The late lamented Luigi Marino, who was the author of several important works on counter-revolutionary thought and, more generally, on the philosophy of Restoration (he had the merit of having once again brought to scholars' attention a central figure such as Gentz), wrote the useful general introduction to the collection, which obliviously dealt extensively with Maistre (La filosofia della Restaurazione, Turin: Loescher, 1978).
} 
extraneous to his broad view. Therefore, it is worthwhile to analyse separately these two levels of Maistre's presence in Italy.

The historiographical and documentary level can be approached by noting the increasing number of volumes that appeared in the new century, consisting in a presentation of Maistre's major works to the Italian public. These translations were definitely more reliable and philologically valid than those published in the early nineteenth century, and often accompanied by a good critical apparatus and well documented introductions. If an early translation of the Essai sur le principe générateur des constitutions politiques (published in Città di Castello in 1921) still presents several limits typical of nineteenth-century translations, the volume edited by Roberto de Mattei and Agostino Sanfratello (Milan: Scheiwiller, 1975) is excellent. The same can be said for the comparison between the second Italian translation of Du pape, published in Florence in 1926, and the excellent and (we can certainly say) definitive Italian translation made by Carlo Pasquali (based on the critical French edition by Jacques Lovie and Joannès Chetail), edited and magisterially introduced by Carlo Bo (Milan: Rizzoli, 1984). The robust maturity of the philological sensibility in the second half of the century clearly produced its fruits. And if an isolated translation of the Cinq paradoxes $^{7}$ (edited by Aurelio Saffi, published in Brescia in 1954) is not particularly relevant, there are other two very recent Italian editions, the first published by Solfanelli in 2005 and the second by Morcelliana in 2009. And Les soirées de Saint-Pétersbourg has been translated twice in less than ten years: the first translation edited by Gennaro Auletta and published in Milan in 1959 and reprinted in Turin in 1966, and the second, excellent indeed (and, as such, 'definitive'), edited by Alfredo Cattabiani and translated by Lorenzo Fenoglio and Anna Rosso Cattabiani (Milan: Rusconi, 1971 and 1986). And one should not forget the very useful collection of writings provided by the Grande antologia filosofica in the section on I tradizionalisti francesi (Milan: Marzorati 1971, edited by Maria Adelaide Raschini, with a long introductory essay), in the volumes I controrivoluzionari, edited by Carlo Galli (Bologna: Il Mulino, 1981, accompanied by a long introductory essay that also represents an effort to draw a comprehensive interpretation), and Il pensiero politico di Joseph de Maistre by Domenico Fisichella

\footnotetext{
7 The title of this work is now known to have been Six paradoxes. This is the title under which it has been published in Joseph de Maistre: Oeuvres, ed. Pierre Glaudes.
} 
(Rome-Bari: Laterza, 1993), which includes, besides a masterly reading of the fundamental theoretical issues of Maistrian thought, large sections of the (never previously translated) De la souveraineté $d u$ peuple. Then, in 1999, there was De la souveraineté du peuple, published, edited by Riccardo Albani (Naples: Editoriale scientifica). And some years earlier, in 1985, Massimo Boffa had offered a new and rich Italian edition, with critical introduction and notes, of the Considérations sur la France (Rome: Editori Riuniti). Also, the collection of selected writings from the letters of the Russian period is very interesting. ${ }^{8}$ Then mention must be made of the success of two Italian editions of the Lettres $\dot{a}$ un gentilhomme russe sur l'Inquisition espagnole, which is definitely the most brilliant, contestable, and contested of Maistre's works (but perhaps for this very reason it has been successfully offered to a large public that is always more and more interested in such topics and fascinated by witch hunts and similar subjects): the first edited by Antonio Piras (Rimini: Il Cerchio, 1998) and the second, very recent but consisting in the reprint of an old anonymous translation made in 1823, published in San Donato Milanese by Pizeta in 2009. And again, in 2000, Il Cerchio published the Breviary of tradition, edited by Alfredo Cattabiani (who also was the editor of Les soirées de Saint-Pétersbourg).

As is evident, publications become more frequent, particularly in recent years. It would be also possible to make the list longer, but the purpose of this essay is not only, or mainly, to provide a bibliography, neither a complete nor a selective one. Rather, it has to be noted how the fact that these translations followed on one another is a symptom (and this is the only reason why I wanted to stress it) of a renovated, or perhaps completely new, interest, of a different sensibility, which has led historians to question the role of the Savoyard, and philosophers (who fortunately are now often inured to perfunctory neoEnlightenment dismissals, which unfortunately are still present in several history of philosophy textbooks, and which are marked by the clichéd and trivial categories of 'reaction' and 'irrationalism') and to re-think, sometimes originally, this or that aspect of his thought. ${ }^{9}$

\footnotetext{
${ }^{8}$ Maistre, Napoleone, la Russia, l'Europa. Dispacci da Pietroburgo (1811-1813), ed. Grazia Farina and Ernesto Galli della Loggia (Rome: Donzelli, 1994).

9 The following are important Italian contributions that present different approaches to the debate regarding the so-called Maistrian 'irrationalism': Maria Luisa Pesante, Un inedito di Walter Maturi: il pensiero di Giuseppe de Maistre, in Miscellanea Walter Maturi (Turin: Giappichelli, 1966), 1-13; and Luigi Derla, Joseph de Maistre e l'irrazionalismo, in Studi francesi, 44 (1971), later included in Letteratura e politica tra
} 
Rather, the question could be why one has to await the twentieth century, and even the late twentieth century, to witness such a revived interest. Maybe is it because Maistre is the eternal (and, in this sense, super-historical) witness of a world in crisis, so that, in order to turn to him and listen to him, and to learn to somehow agree with him, we need, in turn, to perceive ourselves as belonging to a world in crisis? Of course, he appears as an interpreter of the twentieth century, more than an interpreter of that nineteenth century which, at least from 1848 onwards, was substantially extraneous to him, although he lived the last twenty years of his life in it: the striking intuition of the 'dialectic of Enlightenment' that causally connects the 'human rights' with the Terror and the guillotine; the prophetic vision regarding the danger of totalitarianism as the violent implosion of instrumental and logical reason abandoned to itself, 'freed' by the sweet chains and hence sinking into nihilism; the fundamental despair, ill-concealed by the unshakeable certainties of those who, perhaps, need to believe and want to believe more than they effectively believe; and, not least, a thought whose reasoning is grounded more on the paradox than on ratio: all this really makes him "one of us" (as Cioran writes ${ }^{10}$ ), more relevant for our world in contraction and decline than for a nineteenth-century world still relying on its "grand destinies and progressive hopes." ${ }^{11}$ And if the 'long century' implodes in 1918, it is not by chance that the writings of the interpreter of the crisis, whose thought was end-to-end an expression of the crisis and an attempt to exorcise it, found new readers as early as the thirties of the 'short century'.

Of course, with regard to a survey of Italian literature-and with an emphasis on specialist studies and monographs-not all the works are

\footnotetext{
la Restaurazione e l'Unità (Milan: Vita e pensiero, 1977), 65-91. An illuminating and lucid reflection on a Maistre considered not as a 'reactionary' and a 'liberticide', but as someone whose thought can suggest a dialectic of freedom alternative to the concept of 'freedom' proposed by the Enlightenment and by the modern rationalism, can be found in Paolo Pastori, "Joseph de Maistre e la libertà," in Rivista internazionale di filosofia del diritto (1978): 336-58.

10 Emile M. Cioran, Joseph de Maistre (Paris: Editions du Rocher, 1957), later republished in Exercices d'admiration (Paris: Gallimard, 1957, 1986).

11 In Italian, "magnifiche sorti e progressive," an expression used by the Italian poet Giacomo Leopardi (1798-1837), which is ironically used in one of his last poems (La Ginestra), to refer to the false knowledge of a "presumptuous and silly century" ("secol superbo e sciocco"), which has forgotten that the power of Nature can destroy very quickly all the human illusions of happiness and progress, in the same way in which Vesuvius destroyed the surrounding Roman cities.
} 
of equal value. There are, for example, relatively naïve contributions, which are not despicable; they are correct in terms of a mere exposition of Maistrian doctrines, but invalidated by an apologetics unbearably aimed at proving the Count right and, therefore, devoid of any critical and interpretative distance-as is the case of Bruno Brunello's book Joseph de Maistre politico e filosofo (Bologna: Patron, 1967). But there are also ridiculous attempts to establish a connection between Maistre's authority principle and fascism, such as Saverio Nasalli Rocca's book Giuseppe de Maistre nei suoi scritti (Torino: Bocca, 1933), which is, by the way, full of mistakes and unacceptable oversights even from a historiographical point of view. Catholic apologetics and fascist totalitarianism: both of these worlds believed they could take possession of Maistre and make him their own champion, especially in Italy. In this way, they fell into opposite and yet similar (and in both cases crushing) errors of perspective, as they saw unilaterally now the one now the other of the faces of that two-faced Janus who- to quote Cioran againwas at the same time Nietzsche and Paul of Tarsus. Each of the two faces turns out to be unbearably deformed, however, if one wants to see only one while hiding the other; and in fact, the paradox consists in the fact that they can be perceived only together, in their indissoluble unity, a unity that-as I am going to show-takes for this very reason the shape of a tragic unity. The essentially tragic dimension of Maistre's thought is the reason why I think it is appropriate to reject any causal relation between it and fascist totalitarianism; to reject it not only when this relation is positively affirmed-as in the aforementioned case of the unacceptable and misleading book by Nasalli Rocca, which in the bargain is also dedicated "to the Duce"!-, but also when it is addressed in the context of a comprehensive diagnosis of the totalitarian illness that was infecting Europe-as it happens in Piero Gobetti's work. For, as I want to reiterate, if it is true that Mastre somehow "foresees" and "foretells" totalitarianism, this does not mean at all that he "wishes" or "paves the way" for it, precisely because he recognises in it the final result of the Enlightenment and of the human autonomy and rebellion: that rebellion whose first sign was represented by the revolutionary Terror. Moreover, the Maistrian principle of the authority conferred by God for the sake of the world is anything but that totalitarian violence (regardless of its political motive) which brutally affirms the power of man over man.

Nevertheless, we also find other scholars, of remarkable intellectual stature, completely extraneous to apologetic ambitions and 
embezzlements. Important works with a focus on historico-philosophical and philosophico-political aspects are Teresa Serra's book Lutopia controrivoluzionaria. Aspetti del cattolicesimo "antirivoluzionario" in Francia (1796-1830) (Naples: Guida, 1977), Vincenza Petyx's book I selvaggi in Europa. La Francia rivoluzionaria di Maistre e Bonald (Naples: Bibliopolis 1987), and the contributions by Sandro Chignola (a scholar who is well known especially for his expertise in Bonald's philosophy and for his 1993 monograph on this subject). ${ }^{12}$ It has to be recalled, however (and this opens a huge problem that we will face later on), that many years earlier, Benedetto Croce also took an interest in Maistre. In Uomini e cose della vecchia Italia (Bari: Laterza, 1927; later reprinted, after an author's revision, in 1943, and again in 1956) Croce focused (among other things) on the letters between Maistre and the Duke of Serracapriola, an interesting testimony of the opinions regarding the situation of Italy from the point of view of two men of the ancien régime of different origins, one a Savoyard and the other a Bourbonist.

In fact, Maistre's name recurs (although not frequently) in Croce's writings. The question of whether elements of Maistre's thought could have influenced Italian historicism (especially Crocian historicism) has been legitimately raised. This question has been particularly discussed by Fisichella, in his 1993 volume mentioned above, with arguments that can be hardly disputed. Furthermore, it should be mentioned that Fisichella is also the author of some of the most important Maistrian studies in Italy, among which Giusnaturalismo e teoria della sovranità in Joseph de Maistre (Messina-Florence: D’Anna, 1963), later included in Politica e mutamento sociale (Lungro di Cosenza: Constantino Marco Editore, 2002), and the more recent Joseph de Maistre pensatore

12 Sandro Chignola, Il concetto controrivoluzionario di potere e la logica della sovranità, in Giuseppe Duso, ed., Il Potere. Per la storia della filosofia politica moderna (Roma: Carocci, 1999); and I controrivoluzionari e il diritto moderno, in Marco Cavina and Francesco Belvisi, Diritto e filosofia nel XIX secolo (Milan: Giuffrè, 2002). The mentioned important monograph is Società e costituzione. Teologia e politica nel sistema di Bonald (Milan: Franco Angeli, 1993): this was the gem of Bonaldian studies in Italy, which then developed with the works of scholars mentioned above, such as Teresa Serra e Vincenza Petyx, and which developed further, in the following years, with Barberis (Giorgio Barberis, Louis de Bonald. Potere e ordine tra sovversione e Provvidenza (Brescia: Morcelliana, 2007) and others. However, and despite the great similarity between Maistre and Bonald (the two "Dioscuri of counter-revolution"), we cannot extend our survey here to the latter. 
europeo (Rome-Bari: Laterza, 2005), which can be considered his main work on this topic.

In his very precise analysis, Fisichella basically distinguishes three interpretative lines regarding the problem of the alleged relation between Maistre and historicism. The first line, mainly represented by Carl Schmitt, sees the Maistrian principle of sovereignty as grounding decisionism, so that Maistre would be "the theorist of crude realism, of the authorative decision, as mere act and fact, as deed of pure power" which, at best, establishes history, but is not included in it.

The second interpretative line sees in Maistre's thought "a neat closure to historical development..., hence the lack of understanding of the meaning of history and of its direction": and here, in relation to the survey of Italian scholarship, Fisichella refers to Furio Diaz's ${ }^{13}$ interpretations (according to which in Maistre "the historiographical interpretation is fostered by passionate motives, and the attraction for practical positions and ethico-political beliefs appears as unmediated, scarcely purified and elaborated by a process of historical reflections"); to Paolo Treves $^{14}$ (who emphasises Maistre's "despair" about the insoluble contrast between thoughts and historical facts, that is, about the inflexible doctrinal coherence disproved by reality); and to Carlo Galli (who, although he acknowledges in Maistre a sort of "unwitting clearsightedness," underlines his "political blindness," his anachronism, "his intimate theoretical inconsistency and logical impossibility" and, hence, "the historical and existential anguish that necessarily follows from all this."

The third interpretative approach that is identified and discussed by Fisichella is more specifically aimed to answer the question mentioned above. This interpretative approach tends to see "in the Maistrian speculative construct a contribution of ideas that has directly opened the doors to modern historicism." ${ }^{15}$ In Italy, this thesis has been supported by Giorgio del Vecchio, who defines the Maistrian perspective as a veritable "political historicism," 16 and by Carlo Antoni, ${ }^{17}$ who maintains

${ }^{13}$ Furio Diaz, Rivoluzione e controrivoluzione, in Luigi Firpo, ed., Storia delle Idee Politiche Economiche e Sociali, 5 vols. (Turin: Utet, 1975), 4.

${ }_{14}$ Paolo Treves, Profeti del passato (Florence: Barbera, 1952).

15 For accounts of other historically minded interpreters of Maistre, see, in this volume, Raphaël Cahen's essay, “The Correspondence of Frederick von Gentz: Receiving Du pape in the German-Speaking World," and Kevin Erwin's essay, "Le mystique de la tradition: Barbey Worships at the Altar of Joseph de Maistre."

16 See Lezioni di filosofia del diritto (Milan: Giuffrè, 1958).

17 See the volume by Carlo Antoni, Lo storicismo (Rome: Eri, 1957), 102-106. 
that in Maistre's thought "there is a cult of History, of a superior pitiless Will" that "is translated, in the practical realm, into the crudest political realism;" it is the idea of "a history that proceeds on its own, according to its internal design," without a proper participation by man-an idea that surprisingly, and yet consequentially, "is then received by the revolutionary left, becoming one of the most effective motives of that movement that can be called "progressive historicism." Therefore, "the principle according to which history has, independently from the arbitrary will of individuals, its own predetermined and irresistible development through which everything, after all, is explained and justified" would be common to both the most severe of the 'reactionaries' and the revolutionists of the new century. Therefore, for Antoni-Fisichella argues-Maistre might be viewed within the framework of "dialectical historicism." Also, Adolfo Omodeo presents a further version of this interpretative approach when, relying on some modern Idealist scholarship that discusses the question of alleged Maistrian 'historicism', he denies that this notion can be properly used, because in Maistre an authentic dialectic of historical development would be missing and, in his thought, "the providential moment destroys the human work." This argument is advanced, in his well-known 1939 book, ${ }^{18}$ through a polemic against those who, in relation to Maistrian works or apophthegms, "celebrate the historicistic concreteness which defeats rationalism" - although he subsequently admits, in his 1955 volume entitled Il senso della storia, that Maistre somehow "takes part in Historicism" together with Hegel and Marx. ${ }^{19}$

In this important debate-which is indeed important in the Italian context where, as is well known, historicism was for a long time a dominant philosophical position-Fisichella's distinctions are extremely clarifying. Therefore, it is worthwhile to quote in full the conclusive key passage of his analysis. In the suggested readings,

Maistre is simultaneously accused of being devoid of any political realism and of falling into the crudest political realism. Concretely, in these two formulations the very word "realism" assumes different meanings. In the first formulation, what is meant is that Maistre is outside of History, that is, that he follows unrepeatable worlds. In the second formulation, what is meant is that he pushes the idea of praxis of power to the extreme

\footnotetext{
18 Adolfo Omodeo, Un reazionario, il conte J. de Maistre (Bari: Laterza, 1939).

19 Omodeo, Il senso della storia (Turin: Einaudi, 1955).
} 
forms of decisional and operational unscrupulousness, without qualms and limits of any kind. ${ }^{20}$

Now, according to Fisichella, the problem is not a confutation of such unilateral readings (something that is quite obvious if one makes a deep analysis of Maistre's thought), but the advancement of another hypothesis, according to which the Maistrian reaction to the Enlightenment would be fostered "on premises derived from classical and Catholic natural law concepts, rather than from historicist premises." 21 This reading is accepted by other scholars, such as Guido Verucci $^{22}$ (who "sees in Maistrian traditionalism not a contribution to the elaboration of nineteenth-century historicism, but rather a conception in which the motives of a sort of naturalist sociology and those of a religious and transcendent providentialism converge and, in his view, are badly combined), and Roberto de Mattei ${ }^{23}$ (who "warns against certain false contemporary readings, particularly the historicist one, upon which basically all the Italian scholars who have focused on the Savoyard thinker have dwelled"), whereas it has been demonstrated-by Fisichella himself-that "the principles of the Maistrian theory of sovereignty are connected to a veritable natural law conception." Thus, Maistre's constant reference to the lesson of history and experience, "far from concluding in an equation traditionalism $=$ historicism, should not let one forget that the natural law is regarded as the yardstick of history, and not as its expression." ${ }^{24}$

The misunderstanding of reading Maistre from the viewpoint of historicism, a misunderstanding from which Italian historiography has particularly suffered, can thus be removed, and with it the misunderstanding of his not better defined 'influence' on Italian historicism and, especially, on Croce's historicism. Personally, I think that Maistre's influences on Italian thought are of a different sort: perhaps they are more hidden and vague (and sometimes not even explicitly declared), but robust and very strong. Through mediations that are, sometimes,

${ }^{20}$ Omodeo, Il senso della storia, 7.

${ }^{21}$ Domenico Fisichella, Il pensiero politico di de Maistre (Rome-Bari: Laterza, 1993). This entire section is indebted to this book by Fisichella, and several passages in quotation marks refer to it.

22 Guido Verucci, La restaurazione, in Luigi Firpo, op. cit., vol. 4, t. 2.

${ }^{23}$ In his Introduction to the already mentioned new Italian translation of the Essai sur le principe générateur des constitutions politiques (Milan: Scheiwiller, 1975).

${ }^{24}$ Fisichella, Il pensiero politico di de Maistre, 8. 
very 'faint' (as I will try to show), Maistre influenced a very specific stream of Italian' thought in the late twentieth century, that is, the decisively anti-Crocian and anti-historicistic stream of Piedmontese thought, with particular reference to Augusto Del Noce and Luigi Pareyson: an influence, by the way, which plays a predominant role on the philosophico-religious level, more than on the political one.

Indeed, the better question is to identify on which line of Piedmontese philosophical thought Maistre's influence has been exerted. As is well known, this thought has developed in two directions, one focused on the primacy of ethics and politics, and the other of more properly religious inspiration. It is in the latter that we find Maistre's legacy: in that which can be defined as 'the other Turin', the less known one, the Turin of religious thinkers, as opposed to a more specifically political stream which includes Gramsci, Gobetti, and Bobbio as major figures. In fact, for instance, the thought of Mazzantini and Del Noce situates itself in ideal continuity with Savoyard-Piedmontese culture. It is a philosophico-religious tradition of thought that goes from Ornato to Gioberti and Bertini, and whose basic components can be identified in ontologism and pessimism (the latter conceived not in a merely psychological sense, but along the lines of that anthropological pessimism, which is already strongly present in Maistre, and yet anchored to a redeeming and completely super-rational hope).

Thus, if ontologism affirms a cognitive immediate relation between God and man, and poses this relation as the ground of knowledge and practice, it follows that through this relation man is defined by his finitude and, at the same time, by his participation in the divine in a horizon of mystery. There are multiple and branched versions, and here it is not possible to pursue them all: therefore, our analysis is limited to a necessarily essential and synthetic survey, to pave the way for a deeper analysis of those figures who are decisive for the purpose of this essay. Firstly, Mazzantini's thought represents an original reading of Thomistic philosophy in a rigorous dialogue with contemporary thought, focused on the value of immanence that Mazzantini intends to oppose. Guzzo's thought leads to the proposal of an idealism that is rich in Platonic and Augustinian traces and that develops in a systematic work directed towards the exploration of essential forms of spiritual life. However, as already recalled, a recurring feature of Torinese culture is represented, together with ontologism, by pessimism conceived as an authentic rejection of reconciliation with existent reality and with its evil. And it should not be forgotten that the emphasis on the centrality of the 
problem of evil is owed to Martinetti, who was Piedmontese (although he taught in Milan).

Furthermore, the reflection on the problem of evil from an anthropological point of view (a specifically Maistrian problem, which pervades all Maistre's works) is at the centre of Del Noce's thought, and represents the starting point for a critical reading of modernity, focused on an original interpretation of atheism, of contemporary Marxism, and of the crisis of our age, which leads to a vindication of traditional thought.

An absolutely original investigation of the problem of evil is represented by Pareyson's 'Philosophy of Freedom', which is continued in the reflections of his student Giuseppe Riconda. From Pareyson's point of view, the question of freedom is the fundamental theme of all modern speculation, which should be fulfilled by a thorough analysis of the outcomes of Existentialism, that is, of that philosophy which has at its centre the relation of Being with freedom. Pareyson's philosophy of freedom represents the final outcome of an idea in which Existentialist appeals, a profound meditation of German Idealism (particularly of Schelling), and Russian thought (that of Dostoyevsky in particular) converge in a hermeneutic framework.

In relation to these topics, Pareyson's philosophy assumes the form of hermeneutics of religious experience related to those aspects of universality that are capable of arousing interest, if not consent, in every man and, hence, it is conceived as an effort to respond to the experience of evil and of suffering that marks human existence. It is necessary to specify, however, that Del Noce identifies in pessimism an authentic philosophical essence, and in this respect his approach is quite different from Pareyson's approach, which is presented as 'tragic thought'.

Furthermore, it is interesting to note that Riconda, who is particularly sensitive to the problem of evil, is inspired by a profound and passionate meditation on Dostoyevsky. In fact, Riconda argues that the fight against evil has nowadays become more and more difficult and insidious. At stake is the opposition not only to an explosion of a violence which is more and more shameless and cruel, but also to the alienation of the contemporary human being, who is suffocated by a more and more incumbent technocratic totalitarianism. In spite of the success of the apologists of nihilism, Riconda thinks that there still are spaces of freedom for the human being, that is, places where the sense of a transcendent hope can be cultivated and maintained. Man can still choose, and perhaps the ultimate sense of history resides precisely 
in this choice that will stay open until the end of times, so that every man, in every moment, is called to decide. Thus, he sees in Christianity the path to overcoming of contemporary nihilism. Nevertheless, this overcoming remains problematic, since it requires a constant investigation and confrontation with the atheist standpoint, because both of them lose topicality and significance if they do not take into consideration their reciprocal possibility. ${ }^{25}$

To recapitulate: reference to tradition, thematisation of evil, and absolute necessity of the choice for or against Christianity. All these themes are genuinely Maistrian, intimately connected with each other, and even coessential; and we find them, differently presented in their reciprocal relation but always coexistent, in this particular line of thought.

A clarifying preamble is now proper and necessary before proceeding to the final part of our analysis. Here I by no means want to present the complex and multiform scenario of Piedmontese philosophicoreligious thought in the twentieth century as a direct Maistrian legacy: this would be absolutely misleading - not only reductive, but mistaken. Not at all: the origins and connections of Piedmontese twentiethcentury thought are various and manifold, as much so as its leading figures. Rather, my goal is to investigate whether it is possible to discover an underground presence of Maistre (in the way one can, so to say, see a watermark only when paper is held up to the light): a Maistre who is, by the way, quite rarely recalled or cited.

For instance, Del Noce, who like no one else in contemporary thought (at least in Italy) insisted on the necessity of rethinking tradition, conceived in a Christian spirit, as the way of stemming nihilism or, better, as the only authentic, lively, and vital alternative to nihilism, rarely cited Maistre's name in his works. The explicit origins of his ontologism are different and (to keep this analysis short, although the stature of this figure would require a more extended treatment) they are to be traced back to that line of thought which derives from Gioberti, and in the confrontation of this line with Marxism and with

\footnotetext{
${ }^{25}$ Regarding this brief introductory synthesis, I refer to the (still unpublished) research pursued by Francesca Volpe, a young scholar from the University of Turin, who has fruitfully focused on this line of thought (I quote quite literally from her work), and with whom I had the chance to converse extensively about this topic. In order to not be too modest, I allow myself to mention that my book Joseph de Maistre pensatore dellorigine (Milan: Mursia, 1986) can be ascribed to this interpretative line.
} 
Gentile's Actual Idealism, conceived as different and opposed, and yet complementary, forms of modern immanentism. Immanentism, atheism, and nihilism, are nothing but further moments of the same movement of thought, as it is shown in Del Noce's 1964 masterpiece, Il problema dell'ateismo (Bologna: Il Mulino).

Now, where does immanentism come from, where does it originate? It comes from the "Cartesian ambiguity," deeply scrutinized and, so to say, dissected by Del Noce in Riforma cattolica e filosofia moderna, published in 1965 (Bologna: Il Mulino). Descartes' introduction of the 'principle of immanence, which in a completely ambiguous and even contradictory way requires for its foundation 'rational arguments' for the existence of God, ends up making the demonstration of such existence completely instrumental and, therefore, substantially extraneous to the real Christian intention. The alternative to this standpoint is represented by Pascal, who always remains in the background as an 'alternative beginning' of modern philosophy. Modern philosophy developed, in its mainstream lines, by developing and strengthening the Cartesian legacy up to the complete explication of the principle of immanence in the great rationalistic systems of the nineteenth century, particularly Hegel's. And the principle of immanence, now transformed into metaphysical rationalism, is reversed (indeed, quite coherently) in Marxism, and at the same time it generates, as a repercussion, Nazifascist totalitarianism. In this way, the principle of immanence consigns the world to the fight between two ideologies that are both, in their fundamental origin, nihilistic and anti-Christian, the former because it regards itself as the last and definitive, completely worldly incarnation of Christianity; the latter because it sees in Christianity, and even more in its early Jewish origin, the enemy that has to be defeated.

In short, ideology and totalitarianism, both mature fruits of the principle of immanence, are intrinsically anti-Christian, and their characteristic inclination is nihilism, which is properly what is left and remains after their implosion, of which Del Noce offers a very sharp interpretation in Il suicidio della Rivoluzione (Milan: Rusconi, 1978). This is a harsh and difficult book, very densely problematic and yet prophetic, if one thinks that it was published for the first time ten years before the collapse of the Soviet Union. A collapse that happened on its own, as is well known, precisely because of an internal implosion, because of consumption, and was not caused by shocks and traumas originated from the outside. It was an emptying, so to say, that precisely 
two centuries later reminds us of the impressive and lucid Maistrian prediction that represents the final achievement of the Considérations sur la France, where it is stated that "the counter-revolution will not be a contrary revolution, but the contrary of revolution."

Indeed, the same pathos can be grasped in Del Noce's book mentioned above, and nevertheless-as in Maistre's work, once againthere is no triumphalism vis-à-vis the sure end of the revolutionary development of the principle of immanence, but rather pessimism, since the revolution that proceeds on its way in the 'winning' West is nihilism-first creeping nihilism, and then triumphant nihilism, as it is now present not only in philosophers' books, but in that common feeling which the books written by philosophers (or by the majority of those who claim to be philosophers) reflect, fondle, allure, and confirm at the same time. Therefore, there is not so much Maistre in Del Noce, if one looks at the letter of his writings-although Maistrian quotes significantly increase, from the first to the last of the books mentioned above-but there is the concrete possibility, I believe, to perceive his pervasive presence. In fact, all the themes that we have succinctly identified in Del Noce are already Maistrian themes, although they sometimes flash undeveloped in Maistre's work. Moreover, these themes are recognisable in the more recent political thought of Vittorio Mathieu, ${ }^{26}$ another leading figure of the Torinese school-although they importantly differ because of an emphasis on the 'Gnostic' aspects of modern rationalism and revolutionism; Gnostic, and thus, once again, antiChristian, but in the sense that they refer to a 'different' possibility for the development of Christianity, which was interrupted in its appearance, but which is always ready to emerge again, like a karst underground torrent.

Furthermore, brave and harsh questioning about the problem of evil is the central subject in the last phase of Luigi Pareyson's thought, which is represented in the writings collected in the posthumous volume Ontologia della libertà (Turin: Einaudi, 1995). It is important to recall that the affirmation of this theme does not represent a 'turn' in the development of Pareyson's thought, but something somehow present since the beginning and through the other phases of his thought: the

\footnotetext{
${ }^{26}$ In this regard I want to recall at least La speranza nella Rivoluzione (Milan: Rizzoli, 1972), second edition (Rome: Armando, 1992); and Cancro in Occidente (Milan: Editoriale Nuova, 1980, 1983).
} 
first phase, which can be summarily defined 'existentialist' (culminating in Esistenza e persona, 1950; but the final edition, enriched by important retrospective elements, is the 1985 one, which was published in Genova by Melangolo); and the 'hermeneutic' phase (culminating in Verità e interpretazione (Milan: Mursia, 1971). It is also important to recall that Pareyson's last phase is grounded on an original and fruitful re-examination of the late Schelling, who also focused on the problem of evil, at least since the 1809 Philosophische Untersuchungen. Unfortunately, because of space limitations, it is not possible to dwell upon these issues; rather, I will focus on the impressive similarity that can be noted between Pareyson's response to the problem of evil, and that offered by Joseph de Maistre (who, once again, is not explicitly mentioned).

According to Pareyson, who refers to Schelling, evil, which is present as a rejected and defeated possibility in God himself, is awakened and reactivated by man though original sin: a mystery which is rationally unfathomable, and yet so serious and powerful that it represents an authentic 'cosmotheandric' cataclysm. It is something that not only hurts human existence, but compromises the whole creation and, hence, involves God himself. Thus, human guilt marks everything that exists so deeply, that it can be redeemed only by suffering, and surely it cannot be corrected and healed by reason. Since, however, human strengths and the human capacity to suffer are not enough to fill the abyss that man himself has created, God's free and voluntary assumption of suffering (through the incarnation of Christ) compensates for it.

This movement of thought is supported, in Pareyson's thought (and this is precisely what is of most interest here), by a passionate meditation on Dostoyevsky's work, which culminates in the famous 1982 essay La sofferenza inutile, later included in the posthumous volume Dostoyevsky. Filosofia, romanzo ed esperienza religiosa (Turin: Einaudi, 1993). Here, starting from the fiery dialogue between Ivan and Alyosha Karamazov, a principle is affirmed, that of the universally redeeming value of suffering and of the meaning that this suffering assumes when, from the point of view of human and 'Euclidean' reason, it can appear totally absurd, meaningless, unjustified and unjustifiable, as it does in the case of the suffering of children and innocent people (this principle is then used again by Pareyson in his 1988 work Filosofia della libertà). Suffering is not only meaningful:

Suffering is the setting for the solidarity between God and humanity: only in suffering can God and humanity join their efforts. It is extremely 
tragic that only in suffering does God succeed in helping humanity, and that only in suffering does humanity manage to redeem itself and raise itself to God. But it is precisely in the mutual suffering of divinity and humanity that it is revealed to be the only force that can get the better of evil. This principle is one of the founding premises of tragic thought: between humanity and God there can be no collaboration in grace if there has not already been collaboration in suffering; without suffering, the world seems enigmatic, and life absurd; without suffering, evil remains unredeemed and joy inaccessible. By virtue of that mutual suffering it is manifested as the living connection between divinity and humanity, as a new copula mundi; and it is for this reason that suffering must be considered the pivot of the rotation from negative to positive, the rhythm of freedom, the heart of history, the pulsation of the real, and the link between time and eternity; in short, a bridge thrown between Genesis and Apocalypse, between the divine origination and the apocatastasis. ${ }^{27}$

Here, in this impressive conclusive passage from Pareyson's posthumous 1995 book, in a context so different and apparently distant-but not so distant if, as it seems certain by now, Dostoyevsky had read Maistre's work and, in any case, Maistre's thought had deeply penetrated Russian spirituality ${ }^{28}$ - the Maistrian mystery of reversibility of the suffering of the innocent for the sake of the guilty ones occurs again: a mystery that represents for Maistre-and also for Pareyson, who is very clear on this point-the core of Christianity and the fulcrum of a choice for or against Christianity itself. Perhaps, following René Girard, one could object that in both cases, despite the due differences, we are dealing with a 'sacrificial' account of Christianity; and there is no doubt that this issue can be discussed, but it is not possible to deny the substantial affinity of thought of the two Savoyards (Maistre and Pareyson), that Dostoyevsky's meditation makes so close and consonant to the reader.

As it has already been recalled, Dostoyevsky's meditation also vivifies Giuseppe Riconda's most recent thought. Riconda is close to Pareyson as well as to Del Noce, and he is able to go through and originally develop their legacy, insofar as he 'grafts' one perspective onto the other, especially in relation to the reflection on the problem of evil,

27 Luigi Pareyson, Ontologia della libertà (Turin: Einaudi, 1995), 478; English trans. Existence, Interpretation, Freedom: Selected Writings, ed. Paolo Diego Bubbio and trans. Anna Mattei (Aurora, CO: Davies Group, Publishers, 2009), 253-4.

${ }^{28}$ See Vera Miltchyna, "Joseph de Maistre's Works in Russia: A Look at their Reception," in Joseph de Maistre's Life, Thought and Influence, ed. Richard A. Lebrun (Montreal and Kingston: McGill-Queen's University Press, 2001), 241-70. 
the reference to tradition, and the demand for a new discovery of Christianity, and he is able to make these perspectives converge onto one another.

Riconda is, in every aspect, the most faithful and, at the same time, the most original heir of Pareyson's lesson, which has been mostly distorted and, so to say, reversed by those of his (direct or indirect) epigones who, through the 'weak thought' (and through-allow me to call it with the name it deserves-the contamination of Derrida's virus), have ended up by allowing the flourishing, within his own school, of precisely that 'image of the mind' which Pareyson himself abhorred more than any other and in which he saw (identifying its image in Dostoyevsky's The Possessed) the supreme danger, that is, the satisfied and pacified nihilism (which today speaks, so to say, from that which once was Pareyson's own chair). Riconda, therefore, represents the alternative (an alternative to which it is necessary to rally around) to such a nihilistic drift, which settled into the legacy of a thought that, more than any other, had scrutinised and dissected nihilism to its very bowels, since, following Dostoyevsky's example, it not only fought against it, but also 'went through' it.

The titles of Riconda's last two books are meaningful: Tradizione $e$ avventura (Torino: SEI, 2001), and the very recent Tradizione e pensiero (Alessandria: Edizioni dell'Orso, 2009). But what is that 'traditional' thought which, according to Riconda, can not only stem nihilism, but represent a lively and perennial alternative to it? Surely not the classical, ontological metaphysics, whose renewed purpose is always, after Heidegger, a hanging back, which can be noble, but is fundamentally fruitless; rather, it is an anthropological conception, which defines man in its relation with Being and truth, in a horizon of mystery and in a situation of sin. Hence, a religious but not irrational idea and, most of all, not a mere set of 'past' truths, but a perennial, and therefore meta-historical, set of principles that are always capable of renovating themselves and of accepting new challenges, drawing from an infinite inexhaustibility that makes such principles capable of illuminating every new and different historical situation. It is the inexhaustibility of the origin, of Being, and of truth-which Riconda admits to reading theologically, or better religiously and in the Christian spirit-that demands from man an ever-new 'creative fidelity': a fidelity that is not a mere clinging to past certainties, but a continuous fight, which is dramatic and constantly exposed to failure. Traditional thought is not static but-and here I use a typical Maistrian metaphor, which seems 
to be totally appropriate-is a thought that lives in time without feeding exclusively on time; it is the 'opposite stream' that, while it falls into the torrent, goes upstream toward the origin. However, this challenge can be accepted, and even won, upon the condition that one does not surrender to the Medusa's gaze of that modern rationalism which, by domesticating first, and then denying the mystery of evil and sin, really paves the way for nihilism.

Here every easy theodicy is out of play: either evil and God, or neither evil nor God. These are the terms of a choice that cannot be delayed or eluded, to which everyone is called: everyone, in his irreducible personality and in his unrepeatable historical situation. It is the ancient, and yet always unavoidable either or, which from Maistre passes to his follower Lamennais, by whom it is formulated, in relation to the indifferentism of the Enlightenment (the son of the Renaissance and seventeenth-century libertinism, and father of contemporary nihilism): either living by faith, or dying in nothingness. This is also Karl Barth's either or, which came to him from Pascal and Kierkegaard, whose philosophies represent a lively presence in Piedmontese philosophicoreligious thought; thus the historical presence of this notion allows one to better appreciate its importance and its speculative value. A speculative value that is also existential tension, in the harsh questionability of which (but without asserting, as already said, any direct derivation) Maistre would have recognised himself, since the reference to tradition, the inescapability of the problem of evil, and the unavoidability of the choice for or against Christianity, are themes that his writings keep suggesting to contemporary thought.

Undoubtedly, he would have recognised himself in the speculative value of the 'either or' - although very few, today, are willing to acknowledge this. The apologist of war, the bard of the executioner, the herald of the alliance between throne and altar... all of these are incorruptible stereotypes, which persist and count. Perhaps it is for this reason that, even there where he is more present, he is rarely cited. This too is a paradox, which is after all worthy of him. But it is not the extreme paradox. In fact the extreme paradox, which perhaps he himself would not reject, as he might appreciate its immense ironic potential, is (to make a circular connection to the passage from his letter to d'Azeglio that I used as a preamble) that Maistre is buried here in Turin, and thus among the Piedmontese people, in the Santi Martiri Church, and precisely on the left of the entrance door, in a street whose name once was Via Dora Grossa. Today, this street is called Via Garibaldi. 